\title{
Guest editorial: The Emilia 2012 earthquakes, Italy
}

\author{
Marco Mucciarelli • Domenico Liberatore
}

Received: 24 April 2014 / Accepted: 26 April 2014 / Published online: 13 May 2014

C Springer Science+Business Media Dordrecht 2014

On May 20th, 2012, at 02:03 UTC (04:03 local time), Emilia region of Northern Italy was struck by an earthquake of local magnitude $M_{L}$ 5.9. The focal mechanism was reverse, with maximum compression along the N-S direction $\left(\operatorname{dip}=46.45^{\circ}\right.$, strike $=103.28^{\circ}$, rake $=93.87^{\circ}$ ). The municipalities that suffered the highest damage were San Felice sul Panaro and Finale Emilia. Many other damaged municipalities were located in the districts of Modena and Ferrara. The main shock was preceded by foreshocks, begun on May 18th, the strongest of which, with local magnitude 4.1, occurred on May 19th at 23:13 UTC. After the main shock, several aftershocks occurred. At 23:00 of May 25th, more than 500 events took place, two of which with $M_{L} \geq 5.0$ (event of May 20th, 13:18 UTC, $M_{L}$ 5.1; event of May 25th, 02:07 UTC, $M_{L} 5.1$ ), and 15 with magnitude ranging between 4.0 and 4.9 (INGV 2012).

On May 29th, at 07:00 UTC, another significant event of magnitude $M_{L} 5.8$ occurred, located nearly $12 \mathrm{~km} \mathrm{~W}$ of the May 20th main event and close to San Felice sul Panaro. This event was followed by two aftershocks of $M_{L} \geq 5.0$. The aftershocks of the May 29th events affected an area elongated according to the $\mathrm{E}-\mathrm{W}$ direction, between the municipalities of Novi di Modena and San Felice sul Panaro, nearly $20 \mathrm{~km}$ long. On June 3rd, a new event of magnitude $M_{L} 5.1$, located to the $\mathrm{W}$ of the previous ones struck the same area (INGV 2012).

The maximum macroseismic intensity, measured according to the European Macroseismic Scale $\left(I_{E M S}\right)$, was VIII in the municipality of Cavezzo as the cumulative effect of the sequence (Tertulliani et al. 2012). In the most damaged municipalities ( $I_{E M S}>$ VII), a few total collapses were observed. Collapses of individual reinforced-concrete (RC) buildings occurred

\footnotetext{
M. Mucciarelli $(\varangle)$

School of Engineering, University of Basilicata, Potenza, Italy

e-mail: marco.mucciarelli@unibas.it

M. Mucciarelli

CRS-OGS, National Institute of Oceanography and Geophysics, Trieste, Italy
}

D. Liberatore

Department of Structural and Geotechnical Engineering, "Sapienza” University of Rome, Rome, Italy 
in the municipalities of San Felice sul Panaro and Finale Emilia, as well as severe damage to monumental buildings and to old constructions.

For the May 20th event the maximum horizontal ground acceleration recorded in the epicentral area was $0.26 \mathrm{~g}$ and the maximum vertical ground acceleration $0.31 \mathrm{~g}$. For the May 29th event the maximum horizontal ground acceleration was $0.31 \mathrm{~g}$ and the maximum vertical ground acceleration an impressive $0.87 \mathrm{~g}$.

de Nardis et al. (2014) compared more than three thousand waveforms, recorded by permanent and temporary stations, with the ground motion prediction equation (GMPE). This formulation underestimates the vertical components, which played an important role in the shaking near the source.

For the May 29th event, Cultrera et al. (2014) computed shakemaps using the permanent stations only and compared the results with data retrieved from higher density temporary stations. Those shakemaps underestimate significantly the ground motion, especially for pseudo-spectral accelerations at long periods.

Barnaba et al. (2014) compared data recorded by a temporary network with GMPE. Peak ground accelerations are in general in good agreement with those predicted by GMPE, whereas predicted peak ground velocities underestimate the observed data. The response spectra follow the trend in peak ground velocities. This behaviour has been interpreted as a site effect due to the deep soft alluvial cover of the Po Plain. An aftershock in June produced peak ground accelerations exceeding three times the values estimated by attenuation laws. Such a great discrepancy could be related to post-critically reflected S-waves and multiples from the Moho. Moho reflections and multiples are investigated by Sugan and Vuan (2013). They define amplitude, frequency, pseudo-spectral accelerations and Housner intensity scaling with magnitude.

Milana et al. (2013) assess the vertical profile of shear-wave velocity through the sedimentary deposits of the Po River alluvial plain above the limestone basement. New information about the velocity structure is added at a scale that is intermediate between the local scale and the regional scale.

For the epicentral area and a return period of 475 years, the present seismic zonation (DMI 2008) specifies an expected maximum horizontal ground acceleration approximately equal to $0.15 \mathrm{~g}$ on stiff soil, and of $0.22 \mathrm{~g}$ on type C soil. Gallipoli et al. (2014) compare values provided by the current Italian seismic regulations with available records. Several differences with respect to horizontal components are observed when the simplified approach for site conditions (based on $V_{s 30}$ classes) is used. On the contrary, when using the more accurate approach based on the local seismic response, a much better agreement is generally obtained.

However, current code regulations are rather recent because the zone was not classified as seismic-prone until 2003. Hence, most of the buildings were not designed to withstand earthquake actions.

There were seven casualties of the main shock of May 20th, of which four were caused by the collapse of three industrial plants at different sites, one by the falling of rubble, and two because of sudden illness (Alberti 2012). The number of casualties was limited due to the earthquake occurring in the night between Saturday and Sunday when most people were in their homes, which were less damaged when compared to industrial plants and churches. A main shock during working hours would probably have resulted in a far greater number of victims. It is also worth mentioning that in the morning of May 20th, First Communion and Confirmation celebrations were scheduled in many parish churches, with foreseeable large crowds. Immediately after the May 29th aftershock, 17 further casualties were reported, most of them being workers involved in the rescue of equipment and goods (Fasano 2012). 
The final number of casualties was 27 (IlGiornaledellaProtezioneCivile.it 2012). The public prosecutors of Ferrara and Modena opened inquiries into the collapse of the industrial plants which caused casualties (Piccolillo 2012).

The emergency response was coordinated by the Department of Civil Protection (DPC). The National Cabinet declared the state of emergency for 60 days in the districts of Bologna, Modena, Ferrara and Mantua, and decided a first allocation of 50 million Euro, together with the suspension of real estate taxes for uninhabitable houses and plants (Pasqualetto 2012b).

On May 23rd, more than 5,000 people were hosted in the tent cities got ready by the DPC, 3,360 of which in the district of Modena and 1,288 in the district of Ferrara; 731 volunteers were deployed by the Emilia-Romagna region, several others came from other Regions (Pasqualetto 2012a). The population assisted reached a maximum of 14,871 people in Emilia-Romagna region, 1,583 in Lombardy region and 64 in Veneto region. 2,540 of them were hosted in hotels (Dolce and Di Bucci 2014).

In addition to the search and rescue, and to the population assistance activities, many technical activities were carried out or coordinated by the DPC: acquisition and dissemination of the accelerometric data from the National Accelerometric Network and the Seismic Observatory of the Structures; evaluation of the liquefaction phenomena; damage and building safety assessment; regulations for the seismic safety assessment of industrial buildings, aimed at a rapid re-establishment of the productive activities; actions undertaken following the evaluations by the Major Risks Commission on the possible evolution of the seismic sequence (Dolce and Di Bucci 2014).

The residential building stock in the area consists of unreinforced masonry and RC buildings. The cultural heritage consists of churches, bell towers, towers, palaces and fortresses. Several industrial plants, mainly of precast concrete, are present in the area, as well as several masonry rural buildings.

Masonry constructions represent a large part of the existing building stock in the area, and the construction of new modern masonry buildings is a common practice. Old masonry buildings are mostly made of fired clay bricks. The seismic performance of these constructions during the seismic sequence was rather good, despite most of them were conceived only to withstand gravity loads (Penna et al. 2013).

RC buildings represent less than $20 \%$ of the whole building stock in the region; most of them are low/mid-rise buildings and were designed for gravity loads only. The observed damage mostly involved non-structural elements such as masonry infills. In few cases brittle failures in RC elements occurred, either caused by local interaction with infills, or by poor reinforcement detailing (Manfredi et al. 2013).

Damage was particularly serious for cultural heritage, rural buildings and industrial plants. These types of buildings have natural period greater than that of ordinary buildings, suggesting that damage was induced by the low frequency components of the ground motion. Moreover, some damage modes highlight a strong influence of the vertical component, as usual for a near-fault earthquake with reverse focal mechanism.

Similarly to what was observed after other Italian earthquakes, the damage to churches was severe. It is often concentrated at the top section of the façade, in the clerestory walls, in the vaults and in the bell towers. The observed damage can be explained according to the local collapse mechanism approach, as only few examples of masonry crumbling were observed, due to the clay brick masonry quality. The performance of the bell towers can be classified into two cases, depending on the bell tower being connected to or separate from the main building, the latter configuration resulting more favourable (Sorrentino et al. 2013a).

The medieval fortresses are a common and distinctive type among the historical constructions of Emilia region. The 2012 earthquakes highlighted their marked vulnerability, 
especially for out-of-plane mechanisms. The most severe damage mainly affects the towers, due to the interaction with the fortress main body. As regards modern interventions, the observed damage highlights the structural incompatibility between the original masonry elements and RC slabs and curbs. On the contrary, traditional interventions (tie-rods or local repointing of mortar bed joints) usually proved to be more effective. An abacus of recurring seismic damage mechanisms has been proposed (Cattari et al. 2013).

Vernacular buildings contribute to shape the rural landscape of Emilia region, and were severely damaged by the 2012 earthquakes, due to their overall layout, constructive details and poor maintenance. Since damage is usually related to local collapse mechanisms, rocking spectra are computed for the near field accelerograms and they are compared with the observed behaviour (Sorrentino et al. 2013b).

The seismic sequence had a great impact on the manufacturing processes in the area (Liberatore et al. 2013). According to the Emilia-Romagna regional government, the direct losses to plants, structures and equipment amount to 2 billion Euro, to which another 3 billion Euro must be added because of the interruption of the production process; these estimations are very close to those provided by the association of industrialists (Ronchetti 2012). Preliminary estimates assessed 5,000 jobs being at direct risk, with an additional 2,000 jobs under threat in the case of a prolonged stop of the production (Bricco 2012).

A very high number of industrial precast buildings were damaged, resulting into most of the casualties, as well as in large economic losses. Whereas most of the damaged and collapsed buildings were designed for gravity loads only, evidence of poor behaviour of some precast buildings designed according to seismic provisions were discovered. The main causes were: failure of connections (especially between beams and columns, resulting in the unseating of the main beams), insufficient ductility of the columns, insufficient stiffness of the roof or slab system (Bournas et al. 2013).

Guidelines for local and global interventions on industrial buildings designed for gravity loads only were firstly drafted (Gruppo di Lavoro Agibilità Sismica dei Capannoni Industriali 2012). Subsequently, the Ministry of Infrastructures and Transportations issued a document for the "Vulnerability assessment and interventions for industrial buildings in seismic prone areas" (Consiglio Superiore Lavori Pubblici 2012).

A generalized seismic retrofit of industrial buildings after the strong shaking of May 20th was initially required. In order to accelerate the recovery of productive activities, this requirement was later loosened, leaving out the buildings which had undergone a strong enough shaking without any damage; the strong enough shaking was defined with reference to the ultimate limit state design earthquake. In Braga et al. (2014) the details of the models are discussed and the computations are carried out to identify the industrial buildings which could be considered as earthquake tested, and therefore not compelled to mandatory seismic retrofit.

The losses to agriculture and cattle-breeding, according to the estimate of Coldiretti, the Farmers Association, amounted to 200 million Euro. 450,000 wheels of Parmigiano Reggiano and Grana Padano have been damaged (Pinardi 2012).

Three main hospital structures in Modena district and one in Ferrara district were evacuated after the main shocks occurred on May 20th and 29th, due to damage to non-structural components and minor structural damage. Regarding content and medical equipment, the survey showed the lack or inadequacy of the restraining details for non-structural components in seismic zones. Accelerometers were installed at the Santa Maria Bianca Hospital at Mirandola. Its performance has been analysed in detail, also making use of a finite-element model properly accounting for the infills (Masi et al. 2013). 
In Castellaro et al. (2013) an interesting case study is analyzed, consisting of two apparently identical tall structures with RC shear walls and stair cores that exhibited a different performance: one did not suffer any damage while the other presented extensive damage in the inner walls. Despite the almost identical geometric configuration, the two structures presented different natural frequencies along the transverse direction, due to a number of structural features (different foundation levels and presumably different material properties, different details etc.). The analysis shows that the different damage can be mainly ascribed to soil-structure interaction, since the damaged structure resulted to be in double resonance with soil, whereas the undamaged one is not.

In conclusion, the papers published in this special issue provide an up-to-date overvieweven though not exhaustive - of the broad spectrum of the scientific and technical issues raised by the Emilia 2012 earthquakes and suggest ways for future research work.

Acknowledgments As Guest Editors of this issue of the Bulletin, we would like to express sincere thanks to the authors for their valuable and original contributions, to the international panel of reviewers, to the Editor of the Bulletin of Earthquake Engineering, Prof. Atilla Ansal, and to the technical staff of Springer.

\section{References}

Alberti F (2012) Il Nord trema 100 volte in un giorno. Corr Sera, 21 May, pp 2-3

Barnaba C, Laurenzano G, Moratto L, Sugan M, Vuan A, Priolo E, Romanelli M, Di Bartolomeo P (2014) Strong-motion observations from the OGS temporary seismic network during the 2012 Emilia sequence in northern Italy. Bull Earthq Eng. doi:10.1007/s10518-014-9610-4

Bournas DA, Negro P, Taucer FF (2013) Performance of industrial buildings during the Emilia earthquakes in Northern Italy and recommendations for their strengthening. Bull Earthq Eng. doi:10.1007/ s10518-013-9466-Z

Braga F, Gigliotti R, Monti G, Morelli F, Nuti C, Salvatore W, Vanzi I (2014) Speedup of post earthquake community recovery: the case of precast industrial buildings after the Emilia 2012 earthquake. Bull Earthq Eng. doi:10.1007/s10518-014-9583-3

Bricco P (2012) A rischio settemila posti di lavoro. Il Sole 24 ore, 23 May, p 37

Castellaro S, Padrón LA, Mulargia F (2013) The different response of apparently identical structures: a far-field lesson from the Mirandola 20th May 2012 earthquake. Bull Earthq Eng. doi:10.1007/s10518-013-9505-9

Cattari S, Degli Abbati S, Ferretti D, Lagomarsino S, Ottonelli D, Tralli A (2013) Damage assessment of fortresses after the 2012 Emilia earthquake (Italy). Bull Earthq Eng. doi:10.1007/s10518-013-9520-x

Consiglio Superiore Lavori Pubblici (2012) Valutazione della vulnerabilità e interventi per le costruzioni ad uso produttivo in zona sismica. http://www.cslp.it/cslp/index.php?option=com_docman\&task=doc_ download\&gid=3437\&\&Itemid=99999999. Last accessed on 30 July 2012

Cultrera G, Faenza L, Meletti C, D'Amico V, Michelini A, Amato A (2014) Shakemaps uncertainties and their effects in the post-seismic actions for the 2012 Emilia (Italy) earthquakes. Bull Earthq Eng. doi:10.1007/ s10518-013-9577-6

de Nardis R, Filippi L, Costa G, Suhadolc P, Nicoletti M, Lavecchia G (2014) Strong motion recorded during the Emilia 2012 thrust earthquakes (Northern Italy): a comprehensive analysis. Bull Earthq Eng. doi:10. 1007/s10518-014-9614-0

DMI (Decreto del Ministro delle Infrastrutture) 14 gennaio (2008) Approvazione delle nuove norme tecniche per le costruzioni. Gazzetta Ufficiale della Repubblica Italiana 2008; 4: Supplemento Ordinario 30

Dolce M, Di Bucci D (2014) National Civil Protection Organization and technical activities in the 2012 Emilia earthquakes (Italy). Bull Earthq Eng. doi:10.1007/s10518-014-9597-x

Fasano G (2012) I 4 in fuga dalla porta sbagliata. Lispezione maledetta di Gianni e Pawan che si preparava a tornare in India con la famiglia. Corr Sera, 30 May, pp 4-5

Gallipoli MR, Chiauzzi L, Stabile TA, Mucciarelli M, Masi A, Lizza C, Vignola L (2014) The role of site effects in the comparison between code provisions and the near field strong motion of the Emilia 2012 earthquakes. Bull Earthq Eng. doi:10.1007/s10518-014-9628-7

Gruppo di Lavoro Agibilità Sismica dei Capannoni Industriali (2012) Linee di indirizzo per interventi locali e globali su edifici industriali monopiano non progettati con criteri antisismici (Guidelines for local and 
global interventions on industrial one-story buildings designed without seismic criteria). http://www.reluis. it/images/stories/Linee_di_indirizzo_GDL_Capannoni.pdf

IlGiornaledellaProtezioneCivile.it (2012) Sisma in Emilia: sono 27 le vittime. http://www.ilgiornaledella protezionecivile.it/index.html?pg=1\&idart=6222. Last accessed on 14 April 2014

INGV (Istituto Nazionale di Geofisica e Vulcanologia) (2012) Terremoto in Pianura Padana-Emiliana - 20 maggio $2012 M_{L}$ 5.9. http://www.ingv.it

Liberatore L, Sorrentino L, Liberatore D, Decanini LD (2013) Failure of industrial structures induced by the Emilia (Italy) 2012 earthquakes. Eng Fail Anal 34:629-647. doi:10.1016/j.engfailanal.2013.02.009

Manfredi G, Prota A, Verderame GM, De Luca F, Ricci P (2013) 2012 Emilia earthquake, Italy: Reinforced Concrete building response. Bull Earthq Eng. doi:10.1007/s10518-013-9512-x

Masi A, Santarsiero G, Gallipoli MR, Mucciarelli M, Manfredi V, Dusi A, Stabile TA (2013) Performance of the health facilities during the 2012 Emilia (Italy) earthquake and analysis of the Mirandola hospital case study. Bull Earthq Eng. doi:10.1007/s10518-013-9518-4

Milana G, Bordoni P, Cara F, Di Giulio G, Hailemikael S, Rovelli A (2013) 1D velocity structure of the Po River plain (Northern Italy) assessed by combining strong motion and ambient noise data. Bull Earthq Eng. doi:10.1007/s10518-013-9483-y

Pasqualetto A (2012a) Gabrielli e la fabbrica “Appena costruita, non doveva crollare”. Corr Sera, 22 May, pp 22-23

Pasqualetto A (2012b) Imu rinviata per le case e le aziende terremotate. Monti: il Paese reagisce. Corr Sera, 23 May, pp 20-21

Penna A, Morandi P, Rota M, Manzini CF, da Porto F, Magenes G (2013) Performance of masonry buildings during the Emilia 2012 earthquake. Bull Earthq Eng. doi:10.1007/s10518-013-9496-6

Piccolillo V (2012) I capannoni finiscono sotto accusa. Non si doveva tornare a lavorare. Corr Sera, 30 May, p 6

Pinardi S (2012) La più colpita è Mantova. Centinaia gli sfollati. Crolli a Palazzo Ducale. Corr Sera, 22 May, p 3

Ronchetti N (2012) La Regione Emilia stima danni totali per 5 miliardi. Il Sole 24 ore, 15 July, p 16

Sorrentino L, Liberatore L, Decanini LD, Liberatore D (2013a) The performance of churches in the 2012 Emilia earthquakes. Bull Earthq Eng. doi:10.1007/s10518-013-9519-3

Sorrentino L, Liberatore L, Liberatore D, Masiani R (2013b) The behaviour of vernacular buildings in the 2012 Emilia earthquakes. Bull Earthq Eng. doi:10.1007/s10518-013-9455-2

Sugan M, Vuan A (2013) On the ability of Moho reflections to affect the ground motion in northeastern Italy: a case study of the 2012 Emilia seismic sequence. Bull Earthq Eng. doi:10.1007/s10518-013-9564-y

Tertulliani A, Arcoraci L, Berardi M, Bernardini F, Brizuela B, Castellano C, Del Mese S, Ercolani E, Graziani L, Maramai A, Rossi A, Sbarra M, Vecchi M (2012) The Emilia 2012 sequence: a macroseismic survey. Ann Geophys 55(4):679-687. doi:10.4401/ag-6140 